\title{
PSYCHOLOGICAL MECHANISMS OF THE DEVELOPMENT OF GENDER IDENTITY OF YOUTH
}

\section{Kikinezhdi O. M.}

\section{INTRODUCTION}

Gender is a basic characteristic of a person that determines his/her psychological and social functioning. Gender identity characterized as being marked by awareness of gender-role cultural standards as well as social and psychological instructions, accepting the traditional or egalitarian modes of behavior, formation of ego-structures in the continuum of masculinity and femininity, by representation of the individual experience of self-knowledge and attitudes to evaluating oneself and others, by agreement and balancing between the real and ideal gender Self.

In our opinion, such phenomenon is vividly represented within the humanitarian and phenomenological approaches, and enables to answer the question about the development of subjectivity, self-expression and acquiring of "Essential I" in the contradictions of life (H. Ball, I. Bekh, M. Boryshevskyi, S. Maksymenko, A. Maslou, V. Romanets, C. Rogers, M. Sliusarevskyi, V. Tatenko, T. Tytarenko). The core of the new methodological approach in national psychology is the idea of a person's subjectivity, which involves the self-determination of its existence in the world, the author's position on events of life, "internal resources of essential self-affirmation" (V. Tatenko ${ }^{1}$ ), which pays the attention on the problem of self-determination in the field of traditional and egalitarian cultures. M. Boryshevskyi accented that "self-concept" is an original standard according to which an individual fixes the process of his/her personal development as growth in various aspects of life: relationships with others (first of all, with "important others"), professional activity, determination, vision of himself/herself in the system of leading vital values"2.

${ }^{1}$ Татенко В. Соціальна психологія впливу : монографія. К. : Міленіум, 2008. 216 с.

2 Боришевський М. Й. Дорога до себе: від основ суб'єктності до вершин духовності : монографія. К. : Академвидав, 2010. С. 8. 
Gender identity within the youth psychology is most significant in the context of personal identification and socio-psychological mechanisms of gender socialization, because on the one hand, it is characterized through the spontaneous learning of gender norms, and on the other hand, through a conscious choice.

The youthful is relates to gender self-determination, the formation of sex-role behavior; the formation of the components of the image of "I" of a man/woman; determination of boundary of identities. According to E. Erickson, this age period is characterized by "identity crisis", diffusion (confusion of roles), the image of "I" with a disorder of identity, which is expressed in diffidence, uncertainty of attitudes to life values, including gender orientations.

The problem of forming gender identity in early youthfulness is scantily investigated, which determined the aim of our study - the determination of the content of gender orientations of youth, their representation in the components of the image of "I", including cognitive, emotional and behavioral components of gender identity.

The most appropriate methods used in the research are: the author's technique for determining the components of the self-concept; the method of unfinished sentences, the compilation of gender autobiography, narrative "Who am I", J. Rotter's" subjective locus of control questionnaire and M. Rokich's ${ }^{4}$ value orientations questionnaire, S. Bem's ${ }^{5}$ test for the determining the psychological sex and the construct of masculinity, femininity, androgyny. The mathematical processing of the study materials was carried out with the standard SPSS package using a nonparametric criterion for verifying the adequacy of revealed difference between the Mann-Whitney U-criteria, calculations of percent rates, and the Student's criterion. Statistical analysis of narrative materials allowed determining the clusters and frequency characteristics of the image of "I" in different spheres of life and their sexual differentiation.

The respondents for the study of sexual self-identification, in particular, the modalities of role and subject plans, were girls and boys 15-17 years old (200 people) who were included in a homogeneous

\footnotetext{
${ }^{3}$ Rotter J. B. Social learning and clinical psychology. NY : Prentice-Hall, 1954.

${ }^{4}$ Rokich M. Beliefs attitudes and values. San Francisco : Jossey-Bass, 1968.

5 Bem S. Sex-role adaptability: One consequence of psychological androgyny. Journal of Personality and Social Psychology. 1975. No. 31. P. 634-643.
} 
educational activity. These were students of 10-11 grades of Ternopil secondary school № 3 specialized in studying foreign languages; students of Ternopil Ivan Franko Ukrainian Gymnasium; and students 18-23 years old (1-3 educational years) of Ternopil Volodymyr Hnatiuk National Pedagogical University (200 people) ${ }^{6}$.

\section{Peculiarities of the formation of the self-concept of a man/woman}

The procedure for conducting the research included studying the age-old, individual and gender characteristics of the development of the self-concept of youth. The author's questionnaire, which includes 60 questions with the 9-point scoring scales, was used. Half of the questions were direct, the other -reversed. The measure of the coherency of the scales was revealed by using the Cronbach coefficient; the normality of the test scales distribution was checked using the Shapiro-Wilka criterion as the most privileged and powerful normality criterion.

The questionnaire included 6 factors by 5 components (scales). The first factor was "Global Self-Esteem, Personal "I" (view of us, self-satisfaction, self-respect, self-regard (scale No. 1, 8, 12, 17, 19). The second factor "Competency "I" (scale No. 2, 9, 16, 22, 26) included potential abilities, professional abilities, individual characteristics, general competence, etc. This factor can be conditionally correlated with the "level of life claims". The third factor "Expected "I" included scales of evaluation from "important others" (scales No. 3, 10, 23, 25, 27). Fourth factor "Bodily "I" included scales: satisfaction with his/her appearance, body, attractiveness (beauty) (scales No. 4, 7, 14, 20, 30). This factor is important for this age. Scales of the fifth factor ("Social "I") showed influence on others, the ability to please, leadership skills, etc. Sixth factor "Self-regulation, self-control" included scales, which evaluated self-activity, self-ability to manage different tasks, social skills, confidence in results, etc. The generalized statistical results of the factors using the "Self-concept" method are presented in Table 1.

${ }^{6}$ Кікінежді О. М. Гендерна ідентичність в онтогенезі особистості : монографія. Тернопіль : Навчальна книга - Богдан, 2011. 400 с. 
Table 1

Inter-correlation scales of the Self-concept method (significant scales at $p<0,05$ for the Spearman correlation coefficient)

\begin{tabular}{|c|c|c|c|c|c|}
\hline \multicolumn{3}{|c|}{ Factor } & \multicolumn{3}{|c|}{$\begin{array}{c}\text { Global self-esteem, personal } \\
\text { "I" }\end{array}$} \\
\hline $\begin{array}{l}\text { Number of } \\
\text { scale }\end{array}$ & 1 & 8 & 12 & 17 & 19 \\
\hline $\mathbf{R}$ & 0,011636 & 0,266451 & 0,271423 & 0,245666 & $-0,211158$ \\
\hline $\mathbf{P}$ & 0,929082 & 0,037924 & 0,034352 & 0,056342 & 0,102353 \\
\hline \multicolumn{3}{|c|}{ Factor } & \multicolumn{3}{|c|}{$\begin{array}{l}\text { Ability to achieve the goal, } \\
\text { Competent "I" }\end{array}$} \\
\hline $\begin{array}{l}\text { Number of } \\
\text { scale }\end{array}$ & 2 & 9 & 16 & 22 & 26 \\
\hline $\mathbf{R}$ & 0,714003 & 0,603670 & $-0,155307$ & 0,768706 & 0,807817 \\
\hline $\mathbf{P}$ & 0,000000 & 0,000000 & 0,232024 & 0,000000 & 0,000000 \\
\hline \multicolumn{3}{|c|}{ Factor } & \multicolumn{3}{|c|}{ Expected "I" } \\
\hline $\begin{array}{l}\text { Number of } \\
\text { scale }\end{array}$ & 3 & 10 & 23 & 25 & 27 \\
\hline $\mathbf{R}$ & 0,218710 & 0,631722 & 0,499078 & 0,183939 & 0,207219 \\
\hline $\mathbf{P}$ & 0,090378 & 0,000000 & 0,000042 & 0,155890 & 0,109068 \\
\hline \multicolumn{3}{|c|}{ Factor } & \multicolumn{3}{|c|}{ Bodily "I" } \\
\hline $\begin{array}{c}\begin{array}{c}\text { Number of } \\
\text { scale }\end{array} \\
\end{array}$ & 4 & 7 & 14 & 20 & 30 \\
\hline $\mathbf{R}$ & 0,853795 & $-0,479669$ & 0,802322 & 0,720085 & 0,771117 \\
\hline $\mathbf{P}$ & 0,000000 & 0,000092 & 0,000000 & 0,000000 & 0,000000 \\
\hline \multicolumn{3}{|c|}{ Factor } & \multicolumn{3}{|c|}{ Social "I" } \\
\hline $\begin{array}{c}\begin{array}{c}\text { Number of } \\
\text { scale }\end{array} \\
\end{array}$ & 5 & 11 & 13 & 18 & 28 \\
\hline $\mathbf{R}$ & 0,655631 & 0,474511 & 0,040174 & 0,741692 & 0,079330 \\
\hline $\mathbf{P}$ & 0,000000 & 0,000112 & 0,758535 & 0,000000 & 0,543368 \\
\hline \multicolumn{3}{|c|}{ Factor } & \multicolumn{3}{|c|}{ Self-regulation, self-control } \\
\hline \begin{tabular}{|c|}
$\begin{array}{l}\text { Number of } \\
\text { scale }\end{array}$ \\
\end{tabular} & 6 & 15 & 21 & 24 & 29 \\
\hline $\mathbf{R}$ & 0,677088 & 0,615676 & 0,663272 & 0,305687 & 0,629240 \\
\hline $\mathbf{P}$ & 0,000000 & 0,000000 & 0,000000 & 0,016586 & 0,000000 \\
\hline
\end{tabular}


In the first factor "Global self-esteem" two scales $($ No. 8, 12) were significant, that is, self-satisfaction and professional opportunities as an orientation to the future, which corresponds to the age-old peculiarities of the youth. Scale No. 19 with a minus sign means a tendency to decrease of self-esteem among high school students, which is caused by not formed emotion and feelings. Self-regard, an adequate evaluation of his/her own features and capability are also in a state of emergency (scales No. 1, 17).

The second factor "Competency "I" included 4 scales (No. 2, 9, 22, 26), such as, potential abilities, physical, mental and general abilities which are prerequisites for forming vital competencies in the future profession. The scale No. 16 with a minus sign proved this fact; however, the ability to achieve goals is still not developed in youth, which is due to the poor personal experience, and their unclaimed in the society. The significance of the two scales (No. 10, 23) in the third factor "Expected "I", means the real dependence of girls and boys on others, first of all, on parents and their assessments, because they are on the verge of independent life.

Responsibility as the main personality feature of this age is forming. Indicators of other three scales (No. 3, 25, 27 - the attitude of others, respect, and expected assessment) are statically insignificant, which means the immaturity of personal "I", the inability to self-represent. All scales of the fourth factor "Bodily "I" were significant, but scales "Dissatisfaction with his/her own physical appearance, body constitution" showed negative indicator, which means the positive perception of appearance by girls and boys. At the same time, low selfesteem of physical "I", dissatisfaction the appearance can be explained by the peculiarities of puberty and mental development, which is in a process of development and the appearance, has not formed yet, because this age is characterized by important changes in the physical development (jump in growth, weight, important physiological processes, and changes in body proportions).

"Social "I" (scale No. 5, 11, 18) included real manifestations of youth, "testing their potency" - the ability to influence others, selfrespect and development of leadership skills. Scales No. 13, 28 (the ability to please and impress on others) were insignificant, which caused by underdevelopment of social and communicative skills of young man and woman. All the scales were important in the factor "Self-control" in 
accordance to the age characteristics of the youth. It points to the development of the behavioral component in the achievement of voluntary self-regulation mechanisms such as the ability to manage with tasks, general competence, development of self-confidence and forming social skills (solving difficulties and problems, manage himself/herself).

The descriptive statistics of the six factors have shown that the most significant factors (in the order of decreasing) were: Competency "I", "Global self-esteem (Personal "I")" and Social I". The revealed triad of factors is confirmation of the age features of gender identity of the youth. L. Bozhovych ${ }^{7}$ outlined that young man and women are "people who are directed to the future". These are the main areas of selfactualization of young people who are on the verge of graduating from school and entering into an independent life (the educational and professional sphere, the construction of their image of "I" (selfpresentation) and the social and communicative sphere (intimate and business communication). The same average value of two factors (Bodily "I" am self-control) shows the end of physical maturity and puberty, the obtaining of adult appearance and the growth of a conscious attitude towards them (self-control). The least average of the factor Expected "I" means a stable vulnerability from the outside society and a little interest to the evaluation from others.

We conducted an empirical study aimed to confirm the assumption that self-concept of boys is more focused on activity in some social spheres; self-concept of girls is under the influence of social standards, which causes more significant "Expected I". "Personal I" (global selfesteem) was the same in boys and girls. However, some indicators such as the ability to achieve goals and persistence are higher in boys than girls. Also, all components of the image of "I" of boys were much higher than girls, except "Expected I".

Differences between boys and girls on all six factors (Table 2) concerned only one statistically significant factor "Expected I", which was much higher in the female-respondents compared with malerespondents $(\mathrm{U}=300 ; \mathrm{p}=0,017)$. There were no statistically significant differences between the other factors, which, in our opinion, can be explained by the imposition of social stereotypes about feminine

7 Божович Л. И. Личность и ее формирование в детском возрасте. М. : Просвещение, 1968. 464 с. 
dependent behavior of girls and women, while young men are directed to increase their status, self-respect and success, forming competence in the public sphere.

The most differences between both sexes are observed on a scale No. 25 ( $U=317 ; p=0,03)$, that is, boys, have higher self-esteem than girls, which is confirmed by studies of other scientists (S. Bem, E. Bendas).

Table 2

Factor analysis of differences between both sexes respondents (by Mann-Whitney U-criterion)

\begin{tabular}{|l|c|c|c|c|}
\hline \multicolumn{1}{|c|}{ Factors } & $\begin{array}{c}\text { Sum of ranks } \\
\text { Boys }\end{array}$ & $\begin{array}{c}\text { Sum of } \\
\text { ranks } \\
\text { Girls }\end{array}$ & U & p-level \\
\hline 1. Global self-esteem & 955 & 937 & 459 & 0,925291 \\
\hline 2. "Competence I" & 1026 & 865 & 400 & 0,348396 \\
\hline 3. "Expect I" & 796 & 1095 & 300 & 0,017298 \\
\hline 4. "Bodily I" & 988 & 903 & 438 & 0,696900 \\
\hline 5. "Social I" & 966 & 926 & 461 & 0,948239 \\
\hline $\begin{array}{l}\text { 6. Self-regulation, } \\
\text { self-control }\end{array}$ & 999 & 892 & 427 & 0,583557 \\
\hline
\end{tabular}

The scales No. $2(\mathrm{U}=346 ; \mathrm{p}=0,08)$ and $24(\mathrm{U}=349 ; \mathrm{p}=0,09)$ are at the level of the tendency, which means a higher evaluation by boys of their own potential abilities, and features of self-confidence as an internationalized feature of male image. The highest rank in the girls had a scale No. 10, which means about their dependence on others, understated self-esteem and may be the result of traditional education. The boys had the highest scales No. 4, 9, 28, which means the satisfaction of young men with their physical attractiveness and appearance.

The refactoring of all scales among male and female respondents, which aimed to discover generalized results showed the presence of two factors. The content of the first factor includes such scales: "Physical I", self-regulation and self-control. The content of the second factor includes such scales: global self-esteem, "Competent I" and "Social I". Therefore, the first factor is called "Personal I", and the second factor - 
"Social I". The first factor includes 7 scales, and the second factor 12 scales.

The important component of our study was the analysis of the connection between the emotional and value attitudes of boys and girls to their appearance and various variables of the self-concept. These were potential abilities, achievements, and available social skills. The image of "Bodily I" was analyzed as a structural component of the image of "I", which is revealed in self-cognition of the physical "I", its selfperception and self-esteem, which depend on the biological sex. The development of self- cognition of youth is directional not to present, but to the future, the disclosure of its potential, unlike teenage, where important changes deal with self-knowledge within "I". It is proved by the 12 scales which are components of the factor "Social I".

The gender differences in the self-concept between girls and boys concerned to one scale of self-respect, which is significantly higher in boys. In our opinion, it is dictated by the social stereotype of young men, and the domination of masculine ideology. As a tendency, there is a difference between potential opportunities and self-confidence: they were higher in boys than girls, which can be interpreted as learned masculine attitudes. Factor analysis didn't show significant differences in male and female respondents. The difference only by the factor "Expected I" was founded, which is statistically significant, higher in girls, and reflecting the subordination, depending girls' self-esteem on the social environment. There are two factors - "Personal I" and "Social I", where significant differences between boys and girls weren't revealed. However, the ranking of places has proven that "Social I" is dominated in the male respondents, while the higher rank of "Personal "I" are respected by girls. Probably it means more oriented boys to gain prestige and success in the public and social sphere; while girls are more focused on increasing self-esteem, on their own personal development. In the process of inheriting previous stereotypes and producing new own values, boys and girls are still at the crossroads of gender selfrealization.

In the process of the analysis, it was found that according to the average indicators of femininity-masculinity (S. Bem's test) masculine orientation dominates among both sexes' respondents with the androgenic type of gender identity. These differences were significant $(\mathrm{t}=2,04 ; \mathrm{p}=0,042)$ (Fig. 1). 


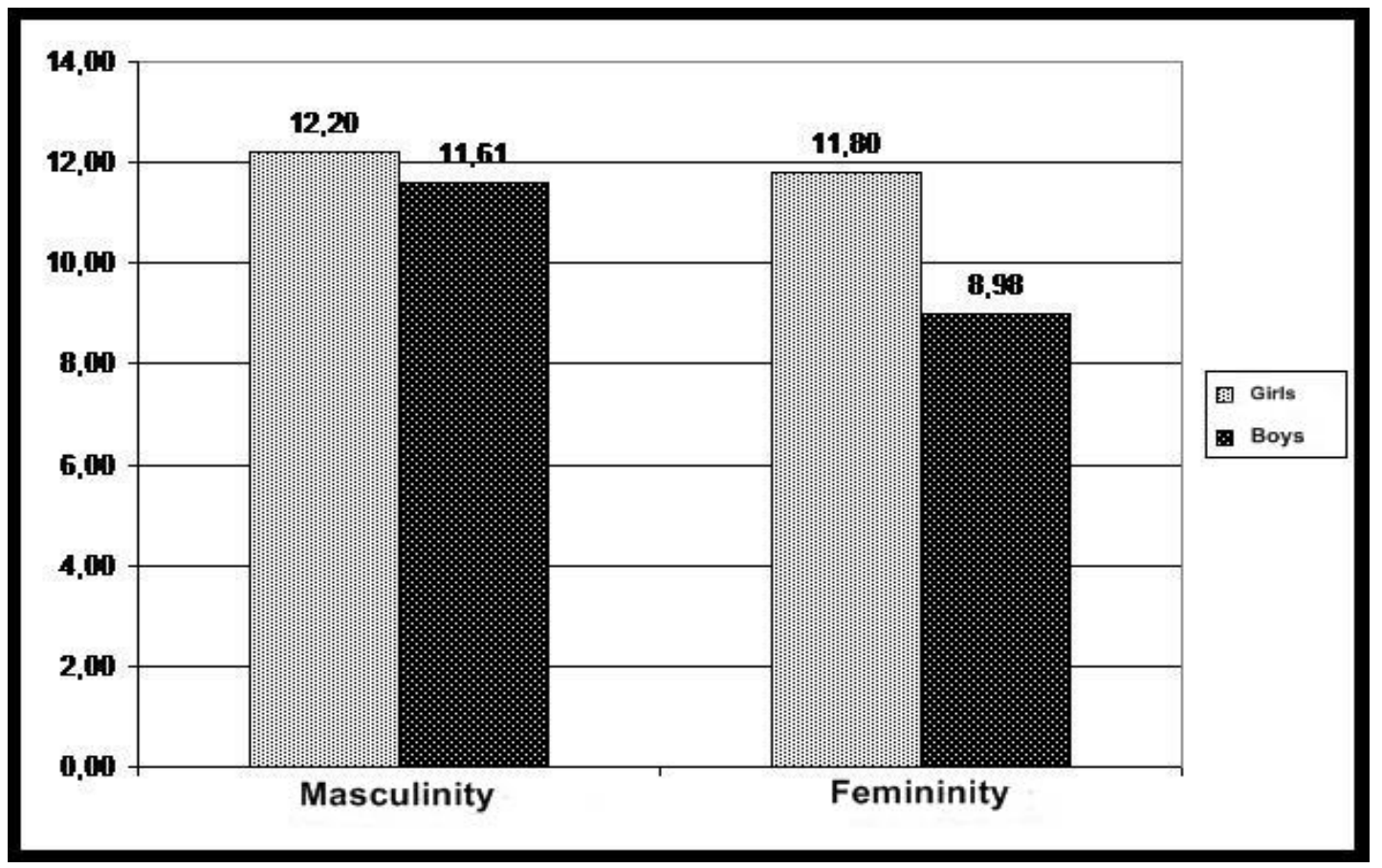

Fig. 1. Distribution of femininity-masculinity among boys and girls

The comparative analysis of the average indicators of masculinity and femininity among both sexes respondents showed significant differences in the scale of femininity in girls in comparison with boys $(t=2,66 ; p=0,0092)$, while differences in masculinity among boys and girls weren't founded. Thus, in a group of girls with an androgenic type of gender identity, orientation towards femininity prevails as a typical female feature ${ }^{8,9}$.

\section{Correlation between the types of gender identity and the level of subjective control}

In the context of our study, it was interested in how the identified types of gender identity and patterns correlate with the level of subjective control of youth. The methodology for diagnosing the level of subjective control has allowed determining the level of locus of control of the world-view formation of personality, which is closely connected

${ }^{8}$ Кікінежді О. М. Гендерна ідентичність в онтогенезі особистості : монографія. Тернопіль : Навчальна книга - Богдан, 2011. 400 с.

${ }^{9}$ Говорун Т. В., Кікінежді О. М., Кравець В. П. та ін. Гендерні дослідження: прикладні аспекти / за наук. ред. В. П. Кравця. Тернопіль: Навчальна книга - Богдан, 2013. $400 \mathrm{c}$. 
with the motivational sphere and the Self-concept. It determines the level of formation of internal responsibility in its manifestations in various spheres of life. It was found that the general internality among respondents of both sexes is lower than normal. The lowest level of internality is observed in the education field $(3,2)$ and in the field of failures (4). The other indicators of the test are in the normal range. Consequently, it can be affirmed that in early youth, where the main activity is educational and professional, boys and girls are experiencing significant difficulties in learning activities, which is related to the social situation of development, the future choice of profession and the entering to independent adult life.

The comparative analysis of the results of boys and girls through the Rotter test showed statistically significantly lower internality of subjective control of girls, compared to boys on all test scales (Table 3). Statistically significant differences between boys and girls are observed on all test scales.

Table 3

Indicators of dispersion analysis

(according to Rotter and S. Bem's tests) (by F-criterion)

\begin{tabular}{|l|c|c|c|c|c|}
\hline & F & P & & F & P \\
\hline Achievements & 107,74 & 0,000000 & Education & 82,35 & 0,000000 \\
\hline Failures & 141,03 & 0,000000 & Relationship & 70,29 & 0,000000 \\
\hline Family & 69,08 & 0,000000 & Health & 50,59 & 0,000000 \\
\hline
\end{tabular}

The major differences between boys and girls are observed in the scales of general internality (by 1,12 steny smaller in girls than in boys) and learning (by 0,61 smaller in girls), which mean internality not only at the level of the outlook but at the level of readiness for activity. After graduating from school, boys are more active than girls; preparing themselves for activities related to success-oriented difficulties. These data are closely correlated with the scale of self-confidence (according to the method of the Self-concept), which is significantly more prevalent among boys than girls. The smallest but statistically significant difference was found on the scale of interpersonal relationship (the difference is 0,45 steny). 
Internality among boys is also higher in such spheres "health" and "family", which is caused by self-realization plans on the future. Thus, we can confirm that girls 15-17 years old have a lower internality than boys. That is, the level of general internality in boys is much higher than girls and higher than the average indicators on all test scales. In girls, externality (external locus of control) prevails, which means their lower autonomy and insecurity in their own forces (Table 4).

Table 4

\section{Correlation between tests of locus of control and gender behavior of youth}

\begin{tabular}{|l|c|c|}
\hline & Masculinity & Femininity \\
\hline General internality & 0,26 & 0,01 \\
\hline Achievements & 0,31 & $-0,03$ \\
\hline Failures & 0,24 & 0,13 \\
\hline Family & 0,32 & 0,06 \\
\hline Study & 0,21 & $-0,10$ \\
\hline Relationships & 0,30 & 0,06 \\
\hline Health & 0,00 & $-0,13$ \\
\hline
\end{tabular}

The data obtained using another method (Self-concept) also confirm our previous results, because it was found a difference in the scale "Expected I" among female respondents, which can be interpreted as a higher girls' dependence on the evaluation from others people or their passivity, etc. Confirmation of our conclusions is also found in the studies of other scientists (E. Ilin, K. Muzdybaev (1983), A. Vizgin \& S. Pantyleev (2001), O. Lazorko (2005), according to which boys' internality is increasing depending on their age; while girls' externality is increasing. In our opinion, it is caused by internalization of stereotypical perceptions of young man and woman in the process of their socialization. Young men have a more internal locus of control, which means a high level of responsibility and internality of general behavior, that is, awareness of themselves as a subject, who can affect external events. Higher dominance and independence are more important values for boys than girls. The significant correlation between 
femininity-masculinity (based on the "raw points" of S. Bem's test) with internment were revealed among female and male respondents.

All scales, except internal in the health sphere, correlate significantly with the masculinity indicator $(p \leq 0,05)$. Thus, we can confirm that high internality is characterized by a person with masculine orientation and young men. The cluster analysis method, the dispersion analysis among male and female respondents allowed selecting three subgroups. Male and female respondents with an androgenic identity type were divided into three clusters, the internality inside of which is approximately equal. The main difference between clusters lies in the general level of internality. The cluster No. 1 is characterized by an equable increasing of the level of internationality $(z>1)$, which is characterized by a small intragroup increasing of internality in the field of failures and decreasing in the health sphere, but these data aren't statistically significant. Cluster No. 2 is characterized by a middling level of internality ( $\mathrm{z}$ from $-0,2$ to $+0,2$ ), insignificant (within normal parameters), increasing of internationality in the sphere of interpersonal relations and decreasing in the field of failures. Cluster No. 3 is characterized by an equable low norm with an insignificant increase of internality in the health sphere ( $\mathrm{z}$ from -0.8 to $-0,6$ ). The representatives of the first cluster (high internality) are only boys (27\%), girls in this cluster are absent. The average internality is characteristic for $24 \%$ of boys and $9 \%$ of girls, while the third cluster (low norm) includes $27 \%$ girls and $13 \%$ of boys.

Cluster analysis allowed revealing three levels of internality in boys and girls with a predominant type of androgenic identity: high, medium and low. The level with a strong low level of internality wasn't revealed. It can be noted that these levels of internality-externality of subjective control of youth don't depend on the type of gender identity. The singlefactor dispersion analysis (ANOVA) indicated close correlations and significant differences between the type of gender orientation (masculinity) and the internality of subjective control (Fig. 2).

The highest indicators of the correlation of internality and masculinity were found among the representatives of the first cluster group, while, there is a significant decrease in the second and third subgroups $(F=3,63 ; p=0,03)$. So, the first cluster, which includes only boys with a high level of internality, is characterized by high 
masculinity. The femininity doesn't have clear patterns related to the cluster of internality $(\mathrm{F}=2,97 ; \mathrm{p}=0,43)$ (Fig. 3).

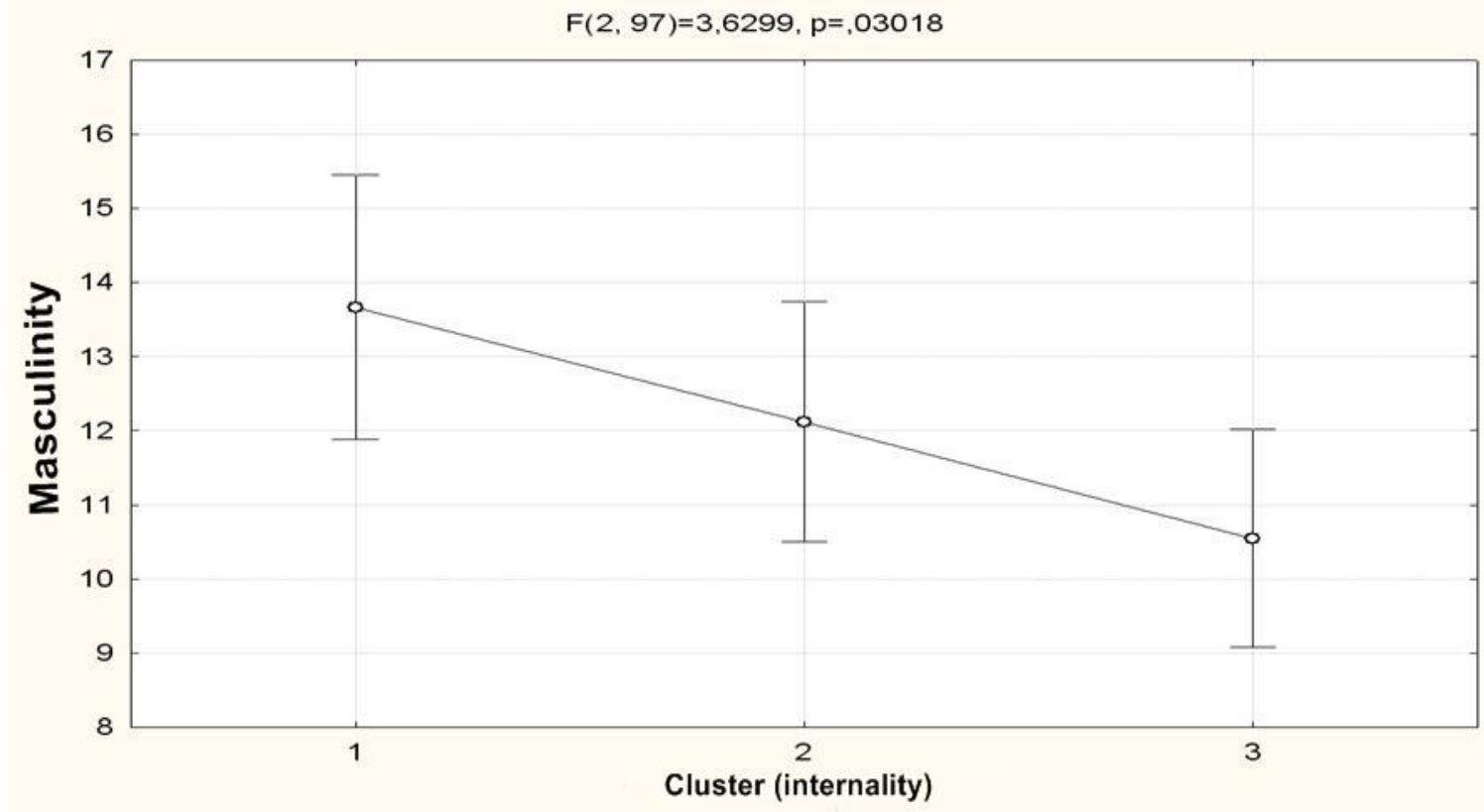

Fig. 2. Graphic representation of the correlation between internality with masculinity among three cluster groups

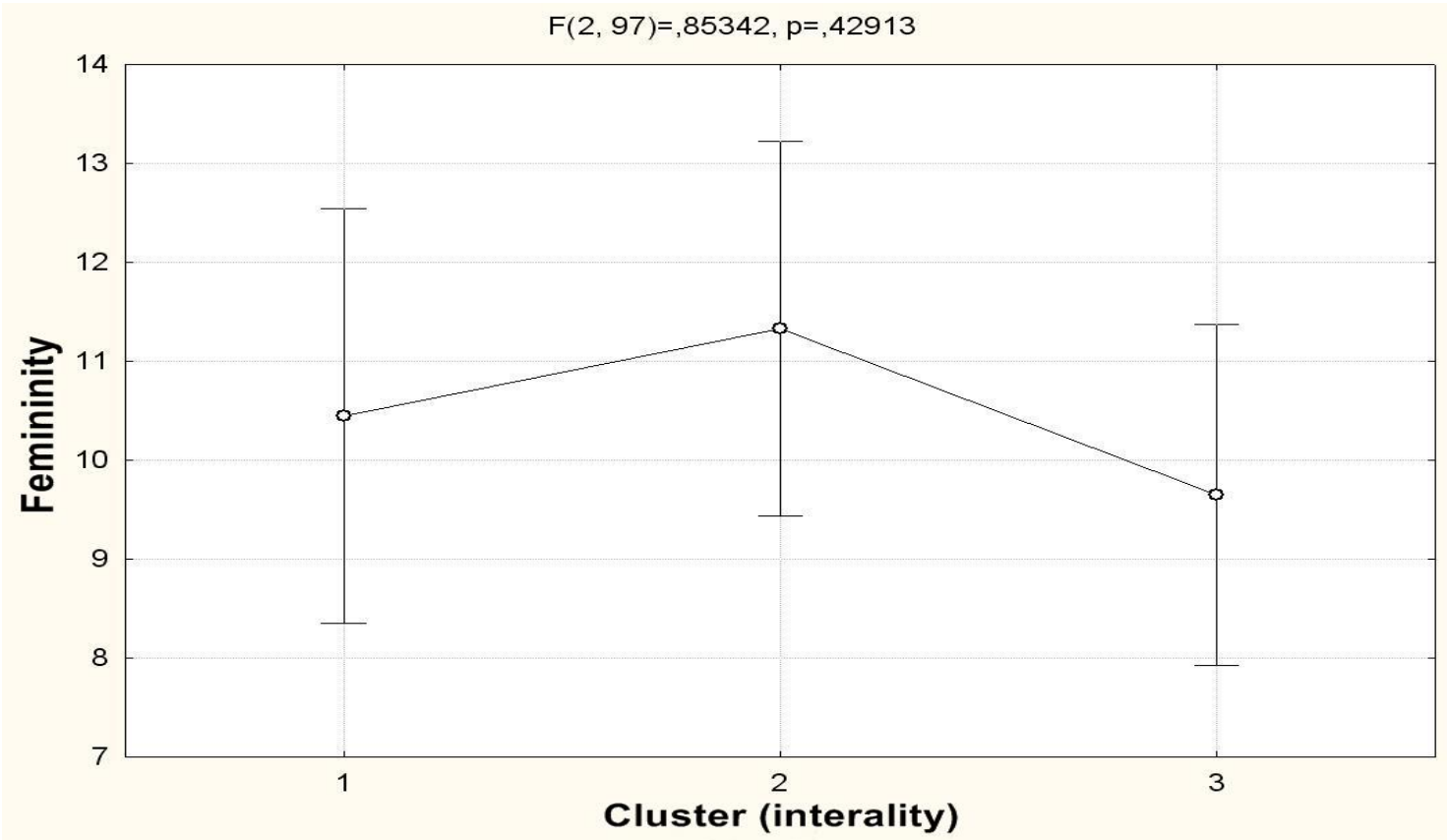

Fig. 3. Graphic representation of the correlation of internality and femininity 
There were no significant differences between the isolated clusters (groups with different levels of internality) and the gender identity (according to S. Bem's test), which was caused by the majority $(80 \%)$ of boys and girls with androgenic identity type. In determining the indicator of gender identity, we assumed (according to L. Ozhihova, M. Rimarev, et al.) that the first four scales of the Liri's test relate to masculine characteristics and the next four - to the feminine ones.

The analysis of the correlation of clusters (levels of internality) with the indicators of femininity-masculinity in real gender "I" (according to the Liri's test) showed the interdependence only between 3 variables. In particular, it was found that the dependence of the friendliness on the type of internality has non-linear character.

The strong friendliness as a feminine feature is observed in the representatives of the second cluster (boys (9\%) and girls (24\%) with an average level of internality). Among the representatives of the first cluster, which includes young men $(27 \%)$, the friendliness is expressed the least.

Representatives of the third cluster, which includes the majority of girls $(27 \%)$ and the minority of boys (13\%), the friendliness is also expressed less to the representatives of the second cluster. It has been found that such a feature as altruism has a similar non-linear dependence on the level of interpersonalism, that is, boys and girls with the middle type of internality have the most expressed altruism.

Representatives of the first and the third type have almost identical tendencies of connection with altruism, which are significant. A similar situation is observed between the level of internality and the friendliness with "significant other" (friends). It was found that the friendship of representatives of the second cluster is significantly higher than in the first and third clusters. Thus, the representatives of the second cluster (with a middle level of internality) are more benevolent (friendly) and altruistic than the representatives of the other two groups.

There are no significant differences between personal qualities (T. Liri's scales) in "Real I", in "Ideal I" and in the evaluation of the "important others". Table 5 shows the correlations between the primary test scales of T. Liri's and masculinity-femininity (according to S. Bem's test). Masculinity positively correlates with authoritarianism $(r=0,378$; $\mathrm{p}=0,00001)$ and egoism $(\mathrm{r}=0,343 ; \mathrm{p}=0,0005)$ in the gender image of "Real I" of girls and boys. 
Table 5

Correlation between the scales of the T. Liri's test and S. Bem's test

\begin{tabular}{|l|c|c|}
\hline & \multicolumn{1}{|c|}{ Masculinity } & Femininity \\
\hline Authoritarianism (real) & $\mathrm{R}=0,378(\mathrm{p}=0,00001)$ & $\mathrm{r}=-0,0861(\mathrm{p}=0,394)$ \\
\hline Egoism (real) & $\mathrm{R}=0,3431(\mathrm{p}=0,0005)$ & $\mathrm{r}=-0,3519(\mathrm{p}=0)$ \\
\hline Aggressiveness (real) & $\mathrm{R}=0,1299(\mathrm{p}=0,198)$ & $\mathrm{r}=-0,234(\mathrm{p}=0,019)$ \\
\hline Suspiciousness (real) & $\mathrm{R}=0,1386(\mathrm{p}=0,169)$ & $\mathrm{r}=-0,2212(\mathrm{p}=0,027)$ \\
\hline Subordination (real) & $\mathrm{R}=-0,0081(\mathrm{p}=0,936)$ & $\mathrm{r}=0,0953(\mathrm{p}=0,346)$ \\
\hline Dependency (real) & $\mathrm{R}=-0,0373(\mathrm{p}=0,713)$ & $\mathrm{r}=-0,0107(\mathrm{p}=0,916)$ \\
\hline Friendliness (real) & $\mathrm{R}=-0,041(\mathrm{p}=0,685)$ & $\mathrm{r}=0,1558(\mathrm{p}=0,122)$ \\
\hline Altruistic (real) & $\mathrm{R}=0,1503(\mathrm{p}=0,136)$ & $\mathrm{r}=0,2201(\mathrm{p}=0,028)$ \\
\hline Authoritarianism (ideal) & $\mathrm{R}=0,1517(\mathrm{p}=0,132)$ & $\mathrm{r}=0,0637(\mathrm{p}=0,529)$ \\
\hline Egoism (ideal) & $\mathrm{R}=0,2198(\mathrm{p}=0,028)$, & $\mathrm{r}=-0,0434(\mathrm{p}=0,668)$ \\
\hline Aggressiveness (ideal) & $\mathrm{R}=0,219(\mathrm{p}=0,029)$ & $\mathrm{r}=-0,0213(\mathrm{p}=0,834)$ \\
\hline Suspiciousness (ideal) & $\mathrm{R}=0,2772(\mathrm{p}=0,005)$ & $\mathrm{r}=-0,2375(\mathrm{p}=0,017)$ \\
\hline Subordination (ideal) & $\mathrm{R}=0,1045(\mathrm{p}=0,301)$ & $\mathrm{r}=0,0375(\mathrm{p}=0,711)$ \\
\hline Dependency (ideal) & $\mathrm{R}=0,087(\mathrm{p}=0,389)$ & $\mathrm{r}=-0,0784(\mathrm{p}=0,438)$ \\
\hline Friendliness (ideal) & $\mathrm{R}=0,0474(\mathrm{p}=0,64)$ & $\mathrm{r}=0,1103(\mathrm{p}=0,274)$ \\
\hline Altruistic (ideal) & $\mathrm{R}=0,0267(\mathrm{p}=0,792)$ & $\mathrm{r}=0,1557(\mathrm{p}=0,122)$ \\
\hline Authoritarianism (other) & $\mathrm{R}=0,3479(\mathrm{p}=0,0004)$ & $\mathrm{r}=0,153(\mathrm{p}=0,129)$ \\
\hline Egoism (other) & $\mathrm{R}=0,3883(\mathrm{p}=0,0001)$ & $\mathrm{r}=0,0029(\mathrm{p}=0,977)$ \\
\hline Aggressiveness (other) & $\mathrm{R}=0,3208(\mathrm{p}=0,0011)$ & $\mathrm{r}=0,0788(\mathrm{p}=0,436)$ \\
\hline Suspiciousness (other) & $\mathrm{R}=0,216(\mathrm{p}=0,031)$ & $\mathrm{r}=-0,0835(\mathrm{p}=0,409)$ \\
\hline Subordination (other) & $\mathrm{R}=0,2321(\mathrm{p}=0,02)$ & $\mathrm{r}=0,13(\mathrm{p}=0,197)$ \\
\hline Dependency (other) & $\mathrm{R}=0,1618(\mathrm{p}=0,108)$ & $\mathrm{r}=0,0831(\mathrm{p}=0,411)$ \\
\hline Friendliness (other) & $\mathrm{R}=0,1432(\mathrm{p}=0,155)$ & $\mathrm{r}=0,1643(\mathrm{p}=0,102)$ \\
\hline Altruistic (other) & $\mathrm{R}=0,07(\mathrm{p}=0,489)$ & $\mathrm{r}=0,09(\mathrm{p}=0,373)$ \\
\hline
\end{tabular}

The femininity negatively correlates with egoism $(\mathrm{r}=-0,3519$ $(\mathrm{p}=0)$, aggressiveness $(\mathrm{r}=-0,234(\mathrm{p}=0,019)$ and suspiciousness $(\mathrm{r}=-0,2212(\mathrm{p}=0,027)$. Femininity positively correlates with altruism $(r=0,22201(p=0,028)$. In the gender image of "Ideal I" among male and female respondents, masculinity positively correlates with egoism $(\mathrm{r}=0,2198(\mathrm{p}=0,028)$, aggressiveness $(\mathrm{r}=0,219(\mathrm{p}=0,029)$ and 
suspiciousness $(\mathrm{r}=0,2772(\mathrm{p}=0,005)$. The femininity is negatively correlated with suspiciousness $(r=-0,2375(p=0,017)$.

Thus, it can be argued that the indicators of femininity and masculinity (according to the S. Bem's test) can be the criteria for the distribution of masculine and feminine scales (according to the T. Liri's test). Taking into account the fact that the gender orientations form the image of "Real I", the indicator of gender identity (according to the T. Liri's test) is calculated only on the basis of the image of "Real I".

The indicator of masculinity has a positive correlation with masculinity (according to the S. Bem's test $(r=0,29 ; p=0,004)$ and negative with femininity $(\mathrm{r}=-0,35 ; \mathrm{p}<0,0001)$. There are no correlations with internality scales. It was found that boys and girls don't differ by the indicator of masculinity (according to the Liri's test) $(\mathrm{t}=-0,059 ; \mathrm{p}=0,95)$. Comparison of boys and girls using the Student's t-criterion, shows the absence of differences between "Real I" and "Ideal I", in the self-esteem and "significant other", but a significant difference was found in the image of "Ideal I" and in the evaluation of the "important others". The harmonization between "Ideal I" and the evaluation of a "significant other" is higher among boys than girls. A high correlation between "Real I" and "Ideal I", self-esteem and the evaluation of a "significant other" $(r=0,97 ; p<0,00001)$ was revealed, which points on the identity (and even interchangeability) of these indicators. Summarizing, they can be called the measure of the adequacy of self-esteem, which doesn't correlate with the indicators of internality.

There are no correlations between the indicators of gender identity (according to S. Bem's test) among both sex respondents. Correlation of the ratio of gender images of "Real I", "Ideal I", and the indicator of masculinity (according to the Liri's test) are: Masculinity and Real-Ideal $(\mathrm{r}=0,25 ; \mathrm{p}=0,012)$; Masculinity and Real-Other $(\mathrm{r}=0,27 ; \mathrm{p}=0,005)$; Masculinity and Ideal-Other $(r=0,27 ; p=0,007)$. These correlations mean the positive influence of masculinity on the harmonization of images.

\section{CONCLUSIONS}

Consequently, gender identity is an aspect of self-consciousness of a personality which is connected with the perception of oneself as a representative of a certain sex. The general Self-concept, formed in 
adolescence, is related to the feeling of adolescence - responsibility for their actions and awareness.

Since gender socialization is specific for men and women, it forms differences in the personality characteristics of boys and girls with different types of gender identity. Thus, the characteristics of the images "I", the level of reflexivity and the level of subjective control, as personality features associated with gender identity.

The main result of the empirical study relate to the way in which some personality features as inconsistency between the expression of the characteristics of the images "Real I" and "Real I" man/"Real I" woman; the images "Real I" man / "Real I" woman and "Ideal I" man/"Ideal I" woman; and the level of subjective control, appears in youth only with an androgenic type of gender identity.

There are no significant differences in the manifestation of the level of internality by boys and girls with an androgenic type of gender identity. Thus, the hypothesis that the fact of inconsistency between the characteristics of the images "I" and the level of subjective control, their correlation with certain types of gender identity, was only partially confirmed.

The referential gender identity ("My Ideal I" and "Perfect I" of my partner) has an appreciable stereotyped character in boys and girls. The priority for the development of gender identity is choosing a profession, a scenario for family life and professional qualifications, but patriarchal attitudes still play a significant role in the components of personal happiness of sexes, their skills, and psychological qualities. Further career is directly divided into "male" and "feminine", and this differentiation is determined by traditional roles in society and family.

Gender identity in adolescence is a generalized image of "I" as a personal entity that characterizes the conscious self-determination of girls and boys in the system of gender values; a higher level of focus on an androgynous model of behavior; the subordination of gender selfidentification to wider social and role self-identification. The conducted research shows a comparatively high level of androgenic personality development in the early youth, while the personal values of girls are more individualized and specific, and the values of young men are more universalized and abstract. In the dynamics of gender identity, the active and conscious activity of the subject dominate in the 
development of his/her own identity, with an orientation on the egalitarian model of behavior.

\section{SUMMARY}

The article deals with an empirical study of the development of gender identity of youth. The formation of the personified image of "I" as the construct of masculine, feminine and androgyny in the context of humanistic, genetic and cognitive psychology, and in accordance with the author's model of sex-role identification of personality is analysed. The specificity of the development of gender identity of girls and boys 15-17 years old concerns the gender differentiation of the structure of terminal and instrumental values, the different ratio of "Ideal I"/"Real I" of representatives of both sexes, their correlation with strategies of gender behavior and subjective control. The general self-concept, which is formed in adolescence, related to the feeling of adulthood responsibility for their behavior, its awareness. It has been found out that the reconstruction of the cognitive component of the gender identity of youth is the result of "creative synthesis" between the aspirations of the internal authentic "I" and the demands of the social environment.

The referential gender identity of girls and boys is strongly stereotyped. Gender identity appears in the generalized, systematized image of acquired sexual sex-role "I"; expanded by the significant influence of its deployment in the sphere of interpersonal relationships; conscious self-determination of girls and boys in the system of gender orientations. It is characterized by the balance of the "Real Gender I" and "Ideal Gender I"; the deepened level of self-reflection, the orientation to different models of sex-role behavior; the subordination of the content of gender identity to the wider socio-role context.

\section{REFERENCES}

1. Божович Л. И. Личность и ее формирование в детском возрасте. М. : Просвещение, 1968. 464 с.

2. Боришевський М. Й. Дорога до себе: від основ суб'єктності до вершин духовності : монографія. К. : Академвидав, 2010. 416 с.

3. Выготский Л. С. Собрание сочинений : в 6 томах / под ред. А. Р. Лурия, М. Г. Ярошевского. М. : Педагогика, 1982. Т. 1. 488 с. 
4. Говорун Т. В., Кікінежді О. М., Кравець В. П. та ін. Гендерні дослідження: прикладні аспекти / за наук. ред. В. П. Кравця. Тернопіль: Навчальна книга - Богдан, 2013. 400 с.

5. Кікінежді О. М. Гендерна ідентичність в онтогенезі особистості : монографія. Тернопіль : Навчальна книга - Богдан, 2011. $400 \mathrm{c}$.

6. Кіммель М. Гендероване суспільство. К. : Сфера, 2003. 490 с.

7. Кон И. С. Социологическая психология. Москва: Московский психолого-социальный институт; Воронеж : Издательство НПО “МОДЭК”, 1999.

8. Максименко С. Д. Генеза здійснення особистості. Київ: TOB “КMM", 2006. 240 c.

9. Маслоу А. Мотивация и личность. СПб. : Евразия, 1999, 478 с.

10. Роджерс К. Взгляд на психотерапию. Становление человека. Москва: "Универс", 1994. 479 с.

11. Татенко В. Соціальна психологія впливу : монографіяю К. : Міленіум, 2008. 216 с.

12. Эриксон Э. Идентичность: юность и кризис. М. : Издательская группа «Прогресе», 1996. 344 с.

13. Юнг К. Г. Проблемы души нашего времени. М. : Прогресс, $1993.310 \mathrm{c}$.

14. Bem S. Sex-role adaptability: One consequence of psychological androgyny. Journal of Personality and Social Psychology. 1975. No. 31. P. 634-643.

15. Hovorun T., Kikinezhdi O.Gender education in humanistic legacy of foreign and Ukrainian pedagogues. Vybrane problemy sucasnej edukacie. - Ruzomberjk, 2010. P. 147-163.

16. Hyde J.-Sh. Half the Human Experience: The Psychology of Women. Lexington - Massachusetts - Toronto, 1991. 475 p.

17. Kohlberg L. A., Ulian D. Z. Stages in the development of psychosexual concepts and attitudes / R. S. Friedman, R. M. Richart \& R. L. Varge Wiete (Eds.), Sex Differences in behavior. New York: Wiley, 1974.

18. Maccoby E. E., Jacklin C. N. The Psychology of Sex Differences. Stanford. CA : Stanford University Press, 1974. 391 p.

19. Marcia J. E. Friedman M. L. Identity in adolescence : handbook of adolescent psychology. Ego identity status in college women. 1970. V. 38. No. 2. P. 249-268. 
20. Rokeach M. Beliefs attitudes and values. San Francisco : JosseyBass, 1968.

21. Rotter J. B. Social learning and clinical psychology. NY : Prentice-Hall, 1954.

\section{Information about the author:} Kikinezhdi O. M.

Doctor of Psychological Science, Professor, Head of the Psychology Department Ternopil Volodymyr Hnatiuk National Pedagogical University, Director of the Scientific Research Centre of the Problems of Gender Education and Upbringing Pupils and Students of NAPS of Ukraine Ternopil Volodymyr Hnatiuk National Pedagogical University 2, Maxyma Kryvonosa str., Ternopil, 46027, Ukraine 